\title{
Occupation Patterns of Amish Settlements in Wisconsin
}

John A. Cross

Professor

Department of Geography

University of Wisconsin-Oshkosh

\begin{abstract}
This article explores occupation patterns of Amish households and settlements in Wisconsin. Wisconsin has seen dramatic growth in Amish settlements over the past 50 years. Using household occupation data reported in Amish directories, dairy producer license listings, and surveys of Amish leaders in 2012 and 2015, this article describes primary household economic activities. Key findings include (1) a rate of 58 percent of Wisconsin's Amish households are employed in some type of farming, (2) 37.4 percent of all Wisconsin Amish households have dairy herds, and (3) in 32 percent of Amish settlements, woodworking jobs dominated. Maps visualize the proportion of households in each settlement engaged in dairying, produce growing, woodworking, carpentry, cabinet and furniture making, and sawmill work, suggesting some spatial patterns. The relationship between occupations and Amish affiliation is also explored.
\end{abstract}

\section{Keywords}

Agriculture; Dairying; Woodworking; Produce growing; Affiliations

\section{Acknowledgements}

The author wishes to thank the two anonymous reviewers for their helpful suggestions and the editor and editorial assistant for their assistance in improving the manuscript. 


\section{Introduction}

Farming has long been the mainstay of the Amish economy, but in much of the Amish homeland, the Amish are entering a variety of non-agricultural trades, industries, and enterprises. Occupational change can be reasonably expected to influence the character of Amish settlements, household structure, and the social and religious dimensions of Amishness. This article addresses occupation patterns in Wisconsin, relates these patterns to geographic factors and Amish affiliations, and poses questions about future occupational changes and research.

Occupational change and its impacts have been studied most thoroughly within the largest and longest-established settlements, including Lancaster County, Pennsylvania (Smith, et al. 1997); Holmes County, Ohio (Nethers 1983; Kreps, Donnermeyer, and Kreps 1994; Lowery and Noble 2000; Hurst and McConnell 2010); Geauga County, Ohio (Foster 1984); and ElkhartLaGrange Counties, Indiana (Nolt and Meyers 2007). Amish population growth in these communities prompted many Amish household heads to turn to non-farm employment (Troyer and Willoughby 1984). As Johnson-Weiner (2014, 6) explains, "Amish communities, particularly the larger, long-established settlements, have faced growing populations, a subsequent lack of affordable farmland, and the need to think about how to confront a more technological future." Nationally it is now estimated that "two-thirds of [Amish] households receive their primary income from non-farm work" (Kraybill, Johnson-Weiner, and Nolt 2013, 291). Furthermore, in both the Elkhart-LaGrange settlement of northeast Indiana and in Geauga County, Ohio, many of the Amish workers are employed in factories that are not owned by the Amish (Meyers 1994; Foster 1984).

In contrast, the majority of Wisconsin's Amish household heads remain in agriculture, as well as woodworking, both rurally-based occupations (Erickson, Ericksen, and Hostetler 1980). In Wisconsin, the largest settlements at the time of this study had only 13 church districts-less than a tenth of the size of the Lancaster, Holmes, and Elkhart-LaGrange settlements (Donnermeyer and Luthy 2013). Wisconsin thus provides an important study site for the exploration of Amish occupation patterns in regions dominated by many small communities without the intense land pressure of large communities. Wisconsin's Amish settlements are also generally more conservative than these larger, more thoroughly studied settlements. Indeed, several of Wisconsin's settlements were established by individuals deliberately choosing to leave places such as the Elkhart-LaGrange settlement so that they would be able to continue with their agrarian lifestyle.

A study of Amish occupational changes has implications for how non-farming occupations may challenge various religious beliefs and social practices. Several decades ago, Foster (1984, 81) concluded that "There was no evidence that any radical changes in values or in behaviors were occurring among Amish factory workers or in districts whose members were predominantly factory workers." Although the Amish have largely accommodated occupational changes while remaining a strong and growing community, changes have been quantitatively documented. Family size, while still large in comparison with non-Amish families, is lower among Amish households working non-agricultural jobs (Wasao and Donnermeyer 1996) and the acceptance of mechanization has been greater in nonfarm jobs than in agriculture (Nolt and Meyers 2007). Qualitative differences in social interactions - both at the family level and with the greater nonAmish world — have also been documented between settlements with different occupational 
profiles. Such changes alter family interactions, child rearing, and the locus of authority when the occupation takes the household head away from the home. Greater use of convenience technology, associated with working away from home, permits more autonomy and could potentially reduce the need for multi-generational family and neighborhood cooperation related to economic and entrepreneurial activities.

While a large share of households is now employed in non-agricultural jobs in large settlements, farm jobs are still held in high esteem. As Hurst and McConnell $(2010,187)$ report, "Most of the Amish men in our survey [in Holmes County] held farming in higher regard than any other occupation." Thus, these large communities have seen some members move to settlements in either those three states or in other states, including Wisconsin.

This paper explores the contemporary occupational patterns of small Amish settlements in Wisconsin. This article first reviews the expansion and spatial distribution of Wisconsin's Amish settlements. Second, it describes primary household economic activities at the settlement level. Third, geographic factors that potentially explain the spatial patterns of engagement in the various occupations within the state of Wisconsin are discussed. Finally, it identifies an association between Amish affiliations and occupational patterns. While this article does not directly test the question of occupational changes on Amish religious and social patterns, it does conclude by noting changes in occupation that are likely to occur over the coming decade and suggesting several questions for further study.

\section{Amish Population Growth in Wisconsin}

The Amish now dominate the small dairy farm landscape in many areas of the country, with those counties that display the largest number of dairy farms (ten through 100 cows) typically including larger Amish settlements (Cross 2007; 2015). Locally, the Amish are well known for their produce and organic agriculture. Yet, other rural-based occupations are increasingly supplementing agricultural employment, if not supplanting farming, in the largest Amish settlements. Although Amish populations are larger in Pennsylvania, Indiana, and Ohio, where the oldest Amish settlements date to the $18^{\text {th }}$ or $19^{\text {th }}$ centuries, by 2015 , Wisconsin was ranked fourth in Amish church districts and had 51 settlements (Figure 1), having grown from two in 1960. Wisconsin's Amish population was estimated at 18,050 in 2016 (Young Center 2016).

Population growth of the Amish in Wisconsin came initially from Amish arriving from older settlements in the Midwest, particularly from Iowa, Indiana, and Ohio. Medford, the oldest surviving Amish settlement in Wisconsin, was established in 1920 by Amish from Kansas, and it soon attracted additional Amish settlers from several Midwestern states (Miller 2009). During the 1960s and 1970s, Amish from other Midwestern communities established most of Wisconsin's new Amish settlements. For example, Amish settlers from Geauga County, Ohio, and Buchanan County, Iowa, established the Cashton settlement in 1965, while the nearby Wilton settlement received its first settlers in 1969 from the Clark/Madison, Missouri, settlement (Miller 2002). The Kingston settlement was started in 1977 by Amish whose roots were in the Elkhart-LaGrange, Indiana, settlement, moving to the area from two Wisconsin Amish settlements that were subsequently abandoned (Miller 2002). Beginning around 1990, Amish began arriving from Pennsylvania, shown by the appearance of surnames, such as Stoltzfus, Allgyer, and Beiler, not previously seen in Wisconsin's Amish communities (Cross 2003; 2016). 


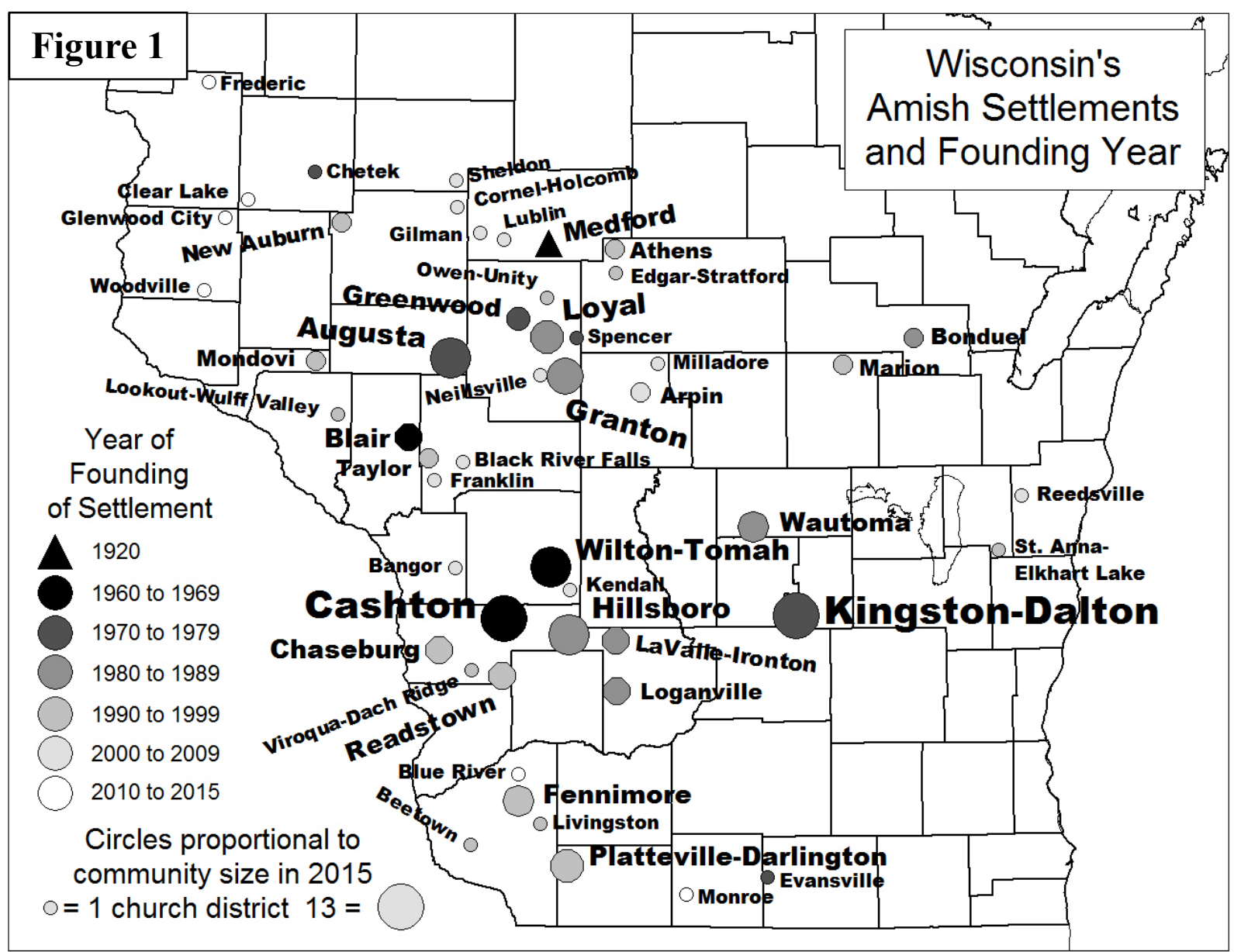

Amish settlements in Wisconsin, founding date, and the number of church districts in 2015. Cartography by author. Sources: Donnermeyer and Luthy (2013) and Raber (2016).

Establishment of new settlements was particularly rapid during the 1990s when 16 were founded. During the eight years running up to the start of the Great Recession in 2008, another eleven were established (Donnermeyer and Luthy 2013). Wisconsin added another eight settlements between the beginning of 2010 and the middle of the decade (Donnermeyer and Anderson 2015).

Given their high birth rates - with the Amish doubling their population every two decades (Donnermeyer 2015) - those Amish who wish to maintain an agrarian lifestyle often choose to migrate to other states. In particular, they have sought locations where many family farms are on the market, populations are declining, and the site is sufficiently far from growing metropolitan areas so that the land prices remain relatively low. These have included many areas in Wisconsin, as well as upstate New York, Kentucky, Tennessee, and Missouri (Anderson and Kenda 2015).

\section{Occupation Data and Research Methodology}

The goal of this study is to document Amish occupational patterns in Wisconsin. Information about occupations of the Amish in Wisconsin comes largely from three sources: (1) directories of Wisconsin Amish, particularly the one published in 2014 (Miller 2009; Miller 2014) and supplemented by information from Raber's "Ministers Lists" that is published annually (Raber 2016); (2) dairy producer license listings, which the author has obtained 
annually for nearly three decades from the Wisconsin Department of Agriculture, Trade, and Consumer Protection; and (3) surveys conducted by the author among Amish bishops and ministers throughout Wisconsin in 2002, 2012, and 2015 regarding employment in agriculture and woodworking, settlement growth, and utilization of technologies, particularly those associated with dairying. While the directories and dairy producer listings provide data at the household level, the survey data aggregates the households such that occupational participation rates among the various settlements can be compared.

The Amish directories provide a plethora of household information. Typically, the mailing address and primary occupation for each household are provided, along with the names and birthdates of each member of the household. Information about the primary occupation, however, pertains only to the husband or male head of household, and a female's occupation is only listed for unmarried adult females, who are listed as separate households. Unfortunately, not all Amish settlements are listed within the directories. For example, while the 2014 Wisconsin Amish Directory included 45 settlements, six were absent (Miller 2014). In addition, occupational data were entirely missing for Cashton in 2014, one of the two largest Amish settlements in the state, but it had been provided in the prior directory (Miller 2009). Furthermore, while the occupational data often, but not always, differentiate households raising produce or operating greenhouses from those engaged in generic "farming," only rarely is mention made regarding dairying. The character and thoroughness of occupation reportage - both farming and woodworking - is not entirely consistent among the settlements. Thus, strategies to deal with missing or incomplete data are necessary, and grouping of related occupations minimizes discrepancies caused by reporting differences.

Two strategies were utilized to estimate or collect missing data. First, size of Amish settlements missing from the published directories can be roughly estimated given their number of church districts and members of the ministry. The names and addresses of Amish bishops, ministers, and deacons for each church district in almost all Amish settlements are included in the "Ministers Lists" updated annually in the Amish-published New American Almanac / Der Neue Amerikanische Calender (Raber 2016). Because these individuals who provide church leadership head roughly a fifth of the households within a church district, their inclusion and number aids in the estimation of the size of Amish settlements not included in the directories. Second, given the role of these individuals in their communities, they also proved excellent sources of information about the families within their church districts. A two-page questionnaire was mailed in 2015 to a minister or bishop in each Amish church district asking specific questions about the total number of households and household numbers engaged in various occupations, such as farming, dairying, growing produce, having a greenhouse, or operating a sawmill or woodworking shop, among other questions. Most questions asking about specific numbers or occupation types were open-ended, although a few questions were multiple choice. Furthermore, given their standing within their settlements, it was expected that the bishops and ministers would be in the best position to provide information, which was sought in the 2002 and 2012 surveys (Cross 2004; 2014) regarding the use of technologies in several occupations, including whether a given technology was permitted by the local district.

The mail surveys generally followed the Dillman (1978) strategy, in which the initial mailing of the questionnaire and cover letter, including a postpaid return envelope, was followed one week later by a postcard, thanking respondents and encouraging non-respondents to 
complete the survey. Three to four weeks after the initial survey mailing, non-respondents were sent another copy of the questionnaire and postpaid return envelope, with a new cover letter encouraging participation. Response rates for the mail surveys conducted between 2002 and 2015 varied between 39 and 45 percent. Because most settlements, with the exception of those with only one church district, had several bishops or ministers surveyed, responses that were received could provide an estimate for the entire settlement. Thus, questionnaires completed by the bishops and ministers provided data where missing from the directories and confirmation of information gathered from the directories. In addition, occupational data were included in the 2009 Wisconsin Amish Directory for Cashton, Gilman, and Taylor, which were missing from the 2014 directory, supplementing information for those settlements that was obtained from the survey. Nevertheless, variations in the data collection methodologies and representation limited the analysis of certain differences among settlements related to their affiliations. This was problematic regarding the Swartzentruber Amish, a particularly conservative affiliation, given the absence of household information for their larger settlements in the directories.

Occupational data regarding dairying among the Amish is likely the most accurately documented. All milk producers are legally required to be licensed to sell their milk. The dairy producer license listings provide the name, mailing address, and barn location (by county, town - Wisconsin's equivalent of the township - and section within the town) for all dairy herds in the state. Cross-referencing the 2015 dairy producer license data with names listed in the Wisconsin Amish Directory 2014 (plus using Raber's Minister's List and distinctive Amish surnames for settlements missing from the directories) identified 1,085 Amish dairy herds in Wisconsin. While the majority of Amish dairy farmers were listed solely as farmers in the directories, some listed farming plus at least one other non-farm occupation.

\section{Agriculture: Dairying}

Dairy farming employs over a third of all Amish household heads (Table 1). The number has grown both absolutely and in proportion to non-Amish dairy farms. In 1989, the Amish ran no more than 475 of Wisconsin's 35,600 dairy herds, and only four towns had Amish running over half of the town's dairy herds. By 2002, the number of Amish dairy farms had nearly doubled, to 865 (Cross 2004), and in 14 towns, the Amish operated over half of the town's dairy herds. In March 2015, the Amish were operating 1,085 dairy farms when Wisconsin's total number fell below 10,000. At that time, in 29 towns, the Amish accounted for over half of all dairy farms. In 2016, just one year later, there were 1,130 Amish dairy herds in Wisconsin, and the Amish operated over half of the dairy herds in 35 towns (Figure 2).

\section{Table 1: Farm Employment of Wisconsin Amish Households in 2014}

\begin{tabular}{ll} 
Type of Farming & Percent of WI Amish Employment \\
\hline Dairy & $37.4 \%$ \\
Produce & $7.6 \%$ \\
Other & $13.1 \%$ \\
\hline All farming types & $58.1 \%$
\end{tabular}




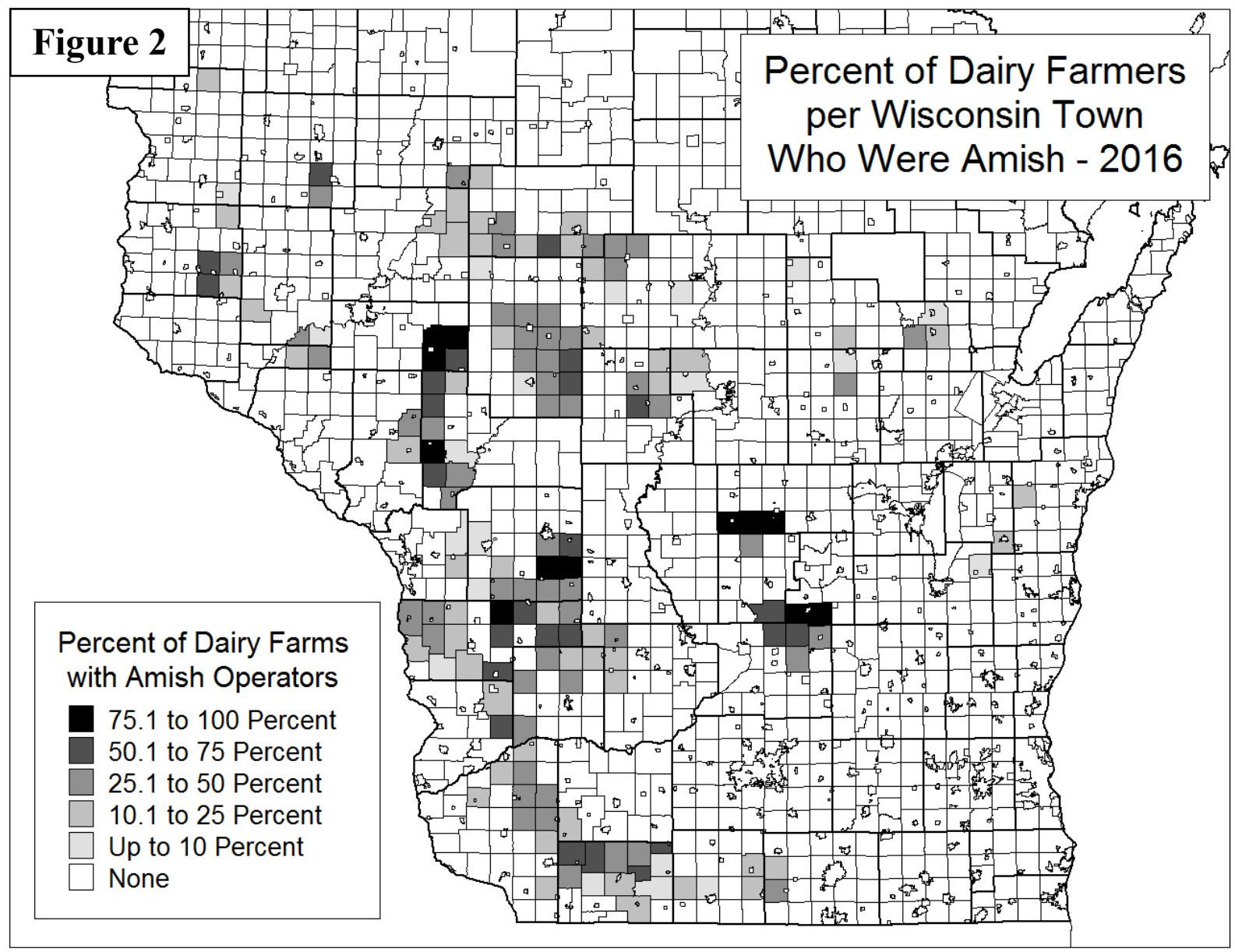

Percent of dairy farms per civil town in Wisconsin operated by the Amish in 2016. Civil towns are Wisconsin's equivalent to a township and typically include 36 one-square-mile sections, although some towns may include more than one Public Land Survey township, or only parts of a survey township. Amish dairy farms were identified by cross-referencing the Amish directory information (Miller 2014) with dairy producer license listings from the Wisconsin Department of Agriculture, Trade, and Consumer Protection, supplemented by use of Amish surnames and Raber's Ministers List for settlements excluded from the directories. Cartography by author.

While the number of Amish dairy farms and their percentage compared to the whole state has grown, the picture is different when comparing percentages within the Amish. Of all Amish farmers, 80 percent had dairy herds in 2002; this dropped to 64 percent by 2014 despite an increase in the actual number of Amish dairy farms. For all non-retiree Amish households, only 37 percent were engaged in dairy farming. This percent varies widely by settlement (Figure 3). On the one end, all households have dairy herds in the settlements of Blue River (Grant County) and Kendall (Monroe County); both are new and quite small. On the other end, none of the households have a dairy herd in Beetown (Grant County), Black River Falls (Taylor County), and in northwestern settlements of Clear Lake (mostly in Barron County) and New Auburn (astride the Chippewa and Barron County line) (see Figure 4). Of the state's two largest Amish settlements - both with 13 church districts - Cashton in 2014 had slightly more than half of its employed households operating licensed dairy herds (129), while the Kingston-Dalton settlement had just under a quarter (60). 


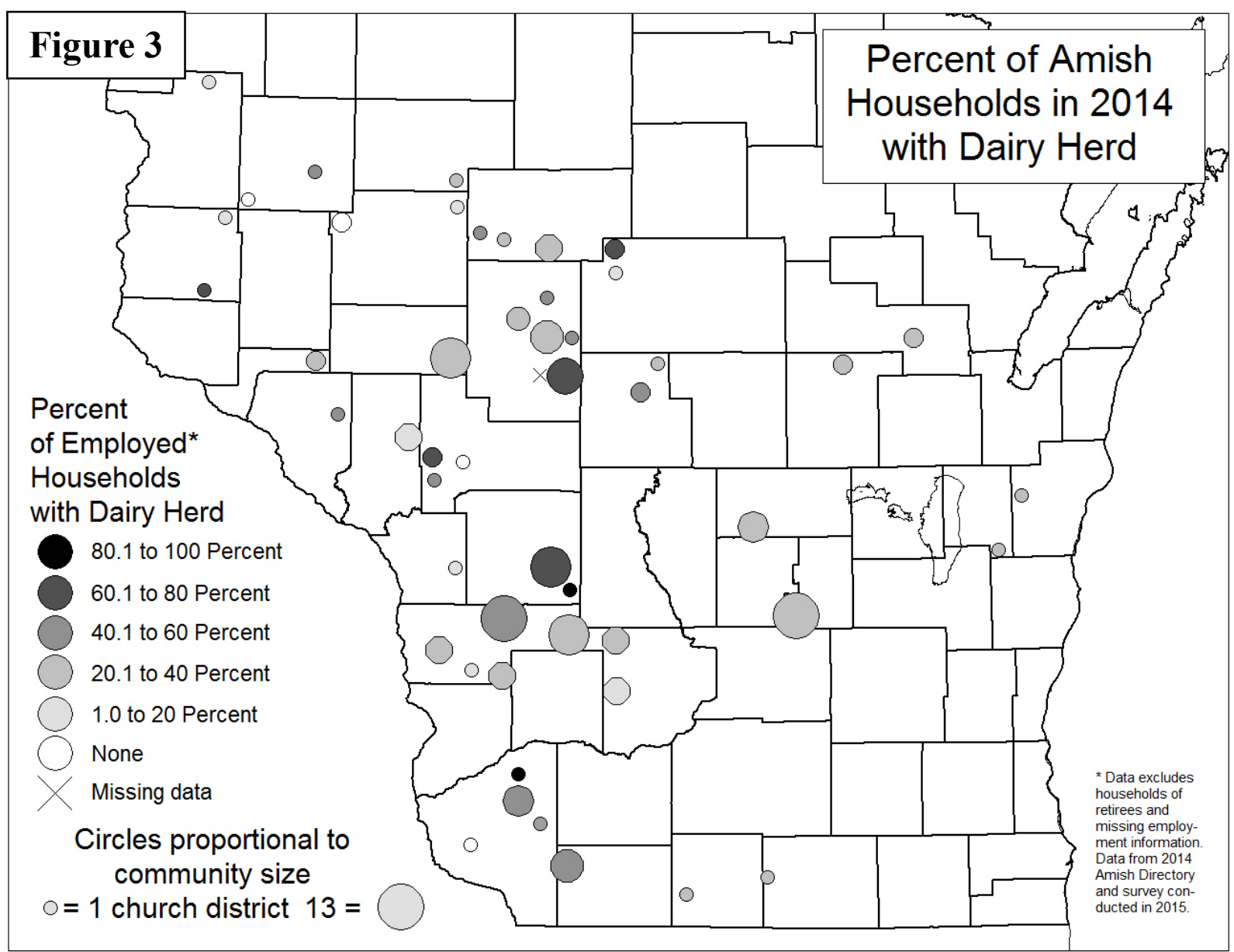

Percent of employed Amish households with a dairy herd in in 2014, by settlement. Primarily based upon Amish directory information (Miller 2014) cross-referenced with the dairy producer license listings from the Wisconsin Department of Agriculture, Trade, and Consumer Protection. Data for communities missing from the directory estimated using results from a survey conducted among Amish bishops and ministers in fall 2015. Cartography by author.

Differing acceptances of many agricultural technologies increasingly distinguish the dairy farming landscape between the most and least restrictive Amish. For example, the five largest Amish settlements in Wisconsin all store and ship their milk using traditional ten gallon cans. These include the Cashton, Wilton, and Augusta settlements, which are Andy Weaver Amish, and the Kingston-Dalton and Hillsboro settlements, which are on the very conservative end of the Old Order-mainstream affiliation (Petrovich 2017). The Ordnung of these settlements excludes many technologies that have been accepted in other settlements (Cross 2004, 2014). For example, Amish settlements using bulk tanks typically permit elevators in the barn, diesel engines for barn usage, corn pickers, and mobile hay balers. These include most of the Old Order-mainstream settlements, including four of the five Wisconsin settlements that associate with the Lancaster County, PA, settlement, as well as those settlements on the progressive end of the Andy Weaver affiliation, including those associating with the Medford, WI, and Buchanan County, IA, settlements. While there is no statistically significant difference in the proportion of farms operating dairy herds between Amish settlements utilizing milk cans and bulk tanks, the share of households that are employed in farming is nearly a third greater in settlements using cans. 


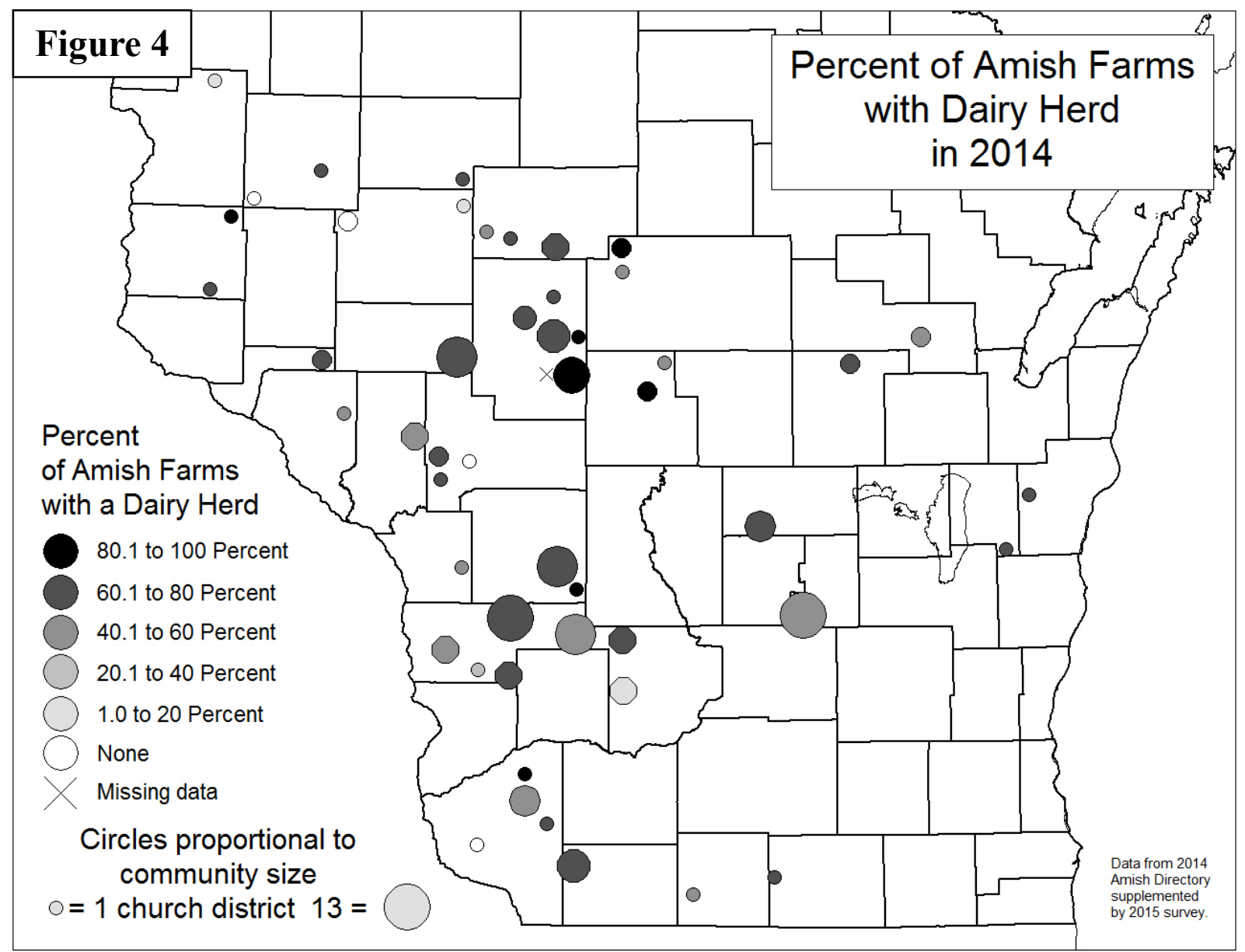

Percent of Amish farms with a dairy herd in 2014, by settlement. Primarily based upon Amish directory information that provided occupation data (Miller 2014) cross-referenced with the dairy producer license listings from the Wisconsin Department of Agriculture, Trade, and Consumer Protection. Data for communities missing from the directory estimated using results from mail survey conducted among Amish bishops and ministers in fall 2015. Cartography by author.

Bulk tanks allow for larger herd sizes. Since 2002, the mean herd size and the mean size of the largest herd per church district have steadily increased where bulk tanks are used. Where milk cans remain in use, the mean herd size has remained nearly unchanged. Indeed, in the 2015 survey, 40 percent of leaders from districts using bulk tanks expected growth in their herd size, while 25 percent of leaders from those prohibiting bulk tanks expected growth. Bulk tanks also provide greater support for full-time employment in dairying. Where bulk tanks are used rather than milk cans, a significantly greater percentage of the Amish obtain half or more of their farm income from milk sales (Table 2). One additional technology that many, though not all, of the settlements adopting bulk tanks permit is the milking machine. Milking machines, along with bulk tanks, further enable dairy farms to have larger herd sizes (Table 3). 


\section{Table 2: Share of Farm Income and Method of Storing and Shipping Milk}

\begin{tabular}{l|cc|c} 
& \multicolumn{2}{|c|}{ "Does the sale of milk provide over } & \multicolumn{2}{|c}{ Milk Storage System } & \\
half of the farm income to members of & Cans & Bulk Tanks & Total \\
your church district?" (2012 survey) & $\mathbf{N = 2 6}$ & $\mathbf{N = 2 2}$ & $\mathbf{N = 4 8}$ \\
\hline YES & $58 \%$ & $91 \%$ & $73 \%$ \\
NO & $42 \%$ & $9 \%$ & $27 \%$ \\
\hline
\end{tabular}

Chi-Square $=6.658,1$ degree of freedom, significance $=.010$

\section{Table 3: Size of Amish Dairy Herds and Method of Storing and Shipping Milk}

\begin{tabular}{l|c|ccc}
$\begin{array}{l}\text { "How many cows are in the } \\
\text { [largest, smallest, average] dairy }\end{array}$ & \multicolumn{3}{|c}{$\begin{array}{c}\text { Type of Amish Dairy Herd and } \\
\text { Number of Milk Cows }\end{array}$} \\
herd in your church district?" & $\begin{array}{c}\text { Year of } \\
\text { Survey }\end{array}$ & $\begin{array}{c}\text { Milk Cans } \\
\text { Bulk Tanks }\end{array}$ & All Amish \\
\hline \multirow{3}{*}{ Largest Herd Mean } & 2002 & 20 & 30 & 26 \\
& 2012 & 23 & 36 & 29 \\
& 2015 & 20 & 43 & 29 \\
\hline \multirow{3}{*}{ Smallest Herd Mean } & 2002 & 7 & 20 & 15 \\
& 2012 & 9 & 18 & 13 \\
& 2015 & 9 & 23 & 13 \\
\hline \multirow{3}{*}{ Average Herd Size } & 2002 & 13 & 24 & 20 \\
& 2012 & 15 & 26 & 20
\end{tabular}

\section{Farming: Produce Growing and Greenhouses}

Farming of all varieties, including dairying, employed 58.1 percent of Wisconsin's Amish households in 2014 (see Table 1). Yet, farming activities are shifting, turning toward produce, organic agriculture, and greenhouses with nursery crops or ornamental plants. Amish involvement with the Organic Valley cooperative in southwestern Wisconsin has been one signal of this shift (Day-Farnsworth 2009).

Statewide, 12.8 percent of Amish households grow produce or greenhouse crops as a primary occupation. The Viroqua-Dach Ridge settlement of Vernon County has the highest percent, at 75 (Figure 5).

In recent years, the Amish have helped establish wholesale produce auction houses in the Cashton, Fennimore, and the Kingston-Dalton settlements. Auction houses have sales several times a week during the growing season (Day-Farnsworth, et al. 2009). Amish with Lancaster County background established the Fennimore produce auction. Two other auctions are in settlements of Old Order-mainstream Amish and a highly conservative Andy Weaver Amish group. The Swartzentruber Amish of Loyal in Clark County have access to a wholesale produce 


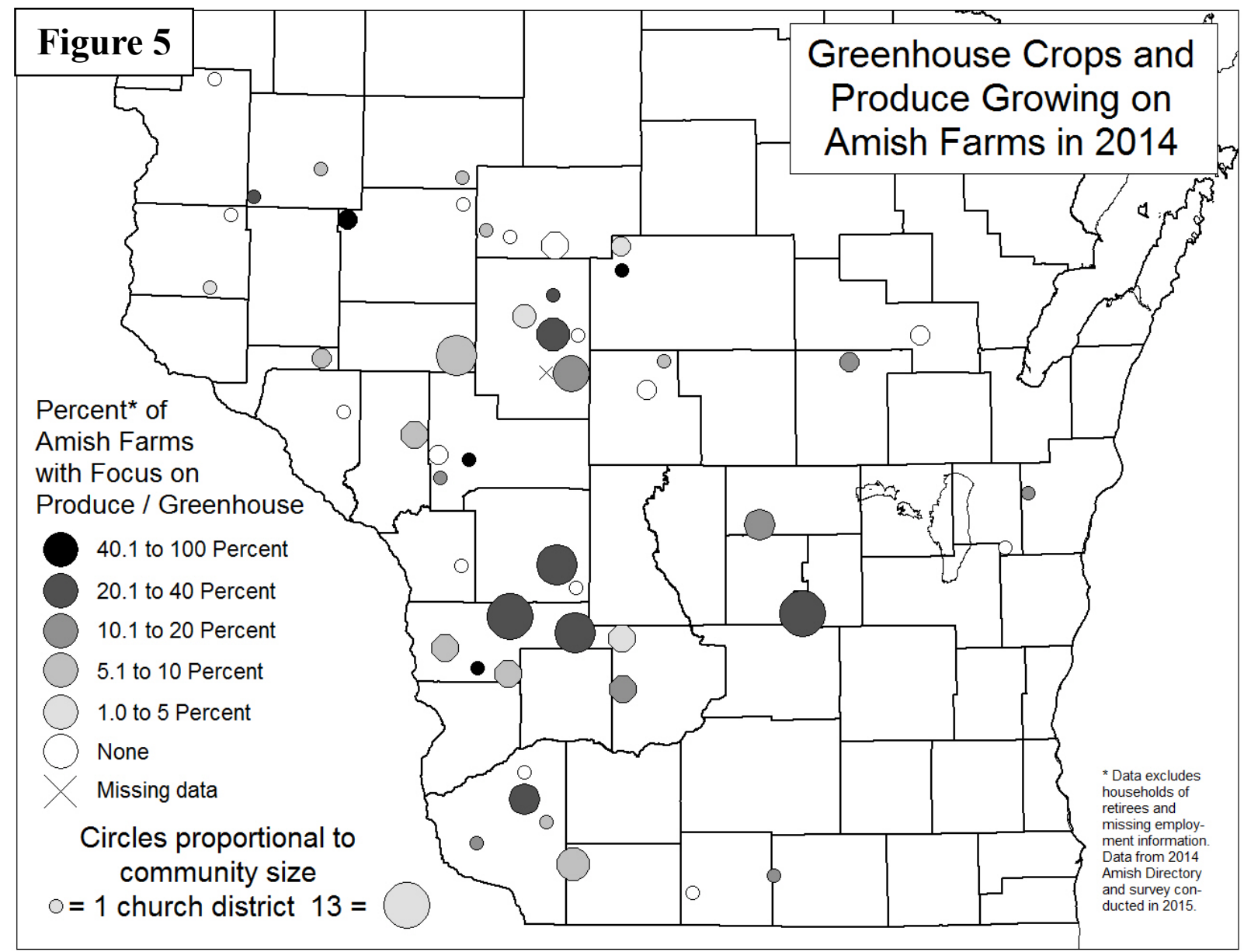

Percent of Amish farms primarily growing produce or greenhouse crops in 2014, by settlement. Primarily based upon occupation data in Amish directory (Miller 2014) supplemented by data from mail survey conducted among Amish bishops and ministers in fall 2015. Cartography by author.

auction house in Withee, just west of the Owen-Unity settlement. The Badgerland Produce Auction, located between the Wautoma and Kingston-Dalton Amish settlements near Montello in Marquette County, has less Amish involvement, particularly since the establishment of a more conveniently located auction between Kingston and Dalton.

Do produce auctions enhance market access for Amish growers? In the survey, ministers were asked about greenhouse and produce farming in their districts. Results suggest that not only are more households involved in these activities than in the 2014 directory but that those communities with or near a produce auction house had the largest share of farmers with greenhouses. For example, one minister in Hillsboro noted the proximity of the Cashton market, about 25 miles distant, when asked if his community had a "wholesale produce auction house." In addition, the survey asked: "By 2025, do you expect that a larger or smaller percentage of the farmers in your church district will grow produce?" Thirty-eight percent of church districts expected increased involvement, with no statistically significant difference between those settlements with and without a produce auction house. The survey also asked whether they expected a produce auction house would be "set up in [their] community during the next several years" if they currently lacked one. Only in Augusta did a respondent indicate such likelihood, and there, it would "depend upon markets." 


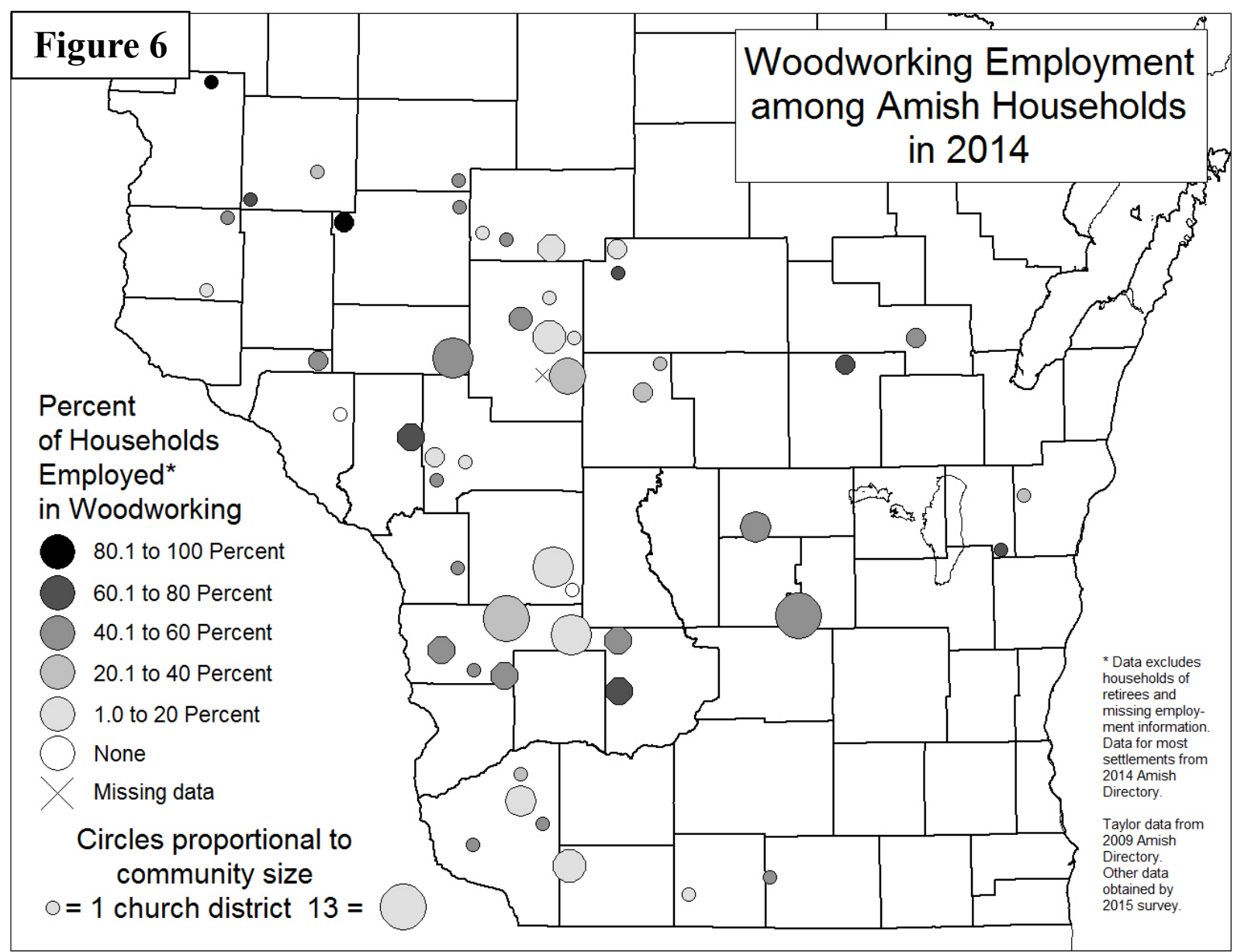

Percent of employed Amish households engaged in woodworking in 2014, by settlement. Primarily based upon occupation data in Amish directory (Miller 2014) supplemented by data from prior directory for several settlements (Miller 2009) and from mail survey conducted among Amish bishops and ministers in fall 2015.

Cartography by author.

Table 4: Woodworking Employment of Wisconsin Amish Households in 2014

\begin{tabular}{|ll|}
\hline Type of Employment & Percent of Employed Households \\
\hline Woodworking (total of all varieties) & $34.5 \%$ \\
\hline Sawmills* & $8.9 \%$ \\
\hline Logging* & $2.1 \%$ \\
Carpenter* & $16.0 \%$ \\
\hline Furniture and Cabinets* & $3.9 \%$ \\
\hline Non-Woodworking & $\mathbf{6 5 . 5 \%}$ \\
\hline
\end{tabular}

* Data from 2014 Amish Directory excludes Cashton, Loyal, and Gilman settlements. These settlements are included in the woodworking total but not within the subcategories. 


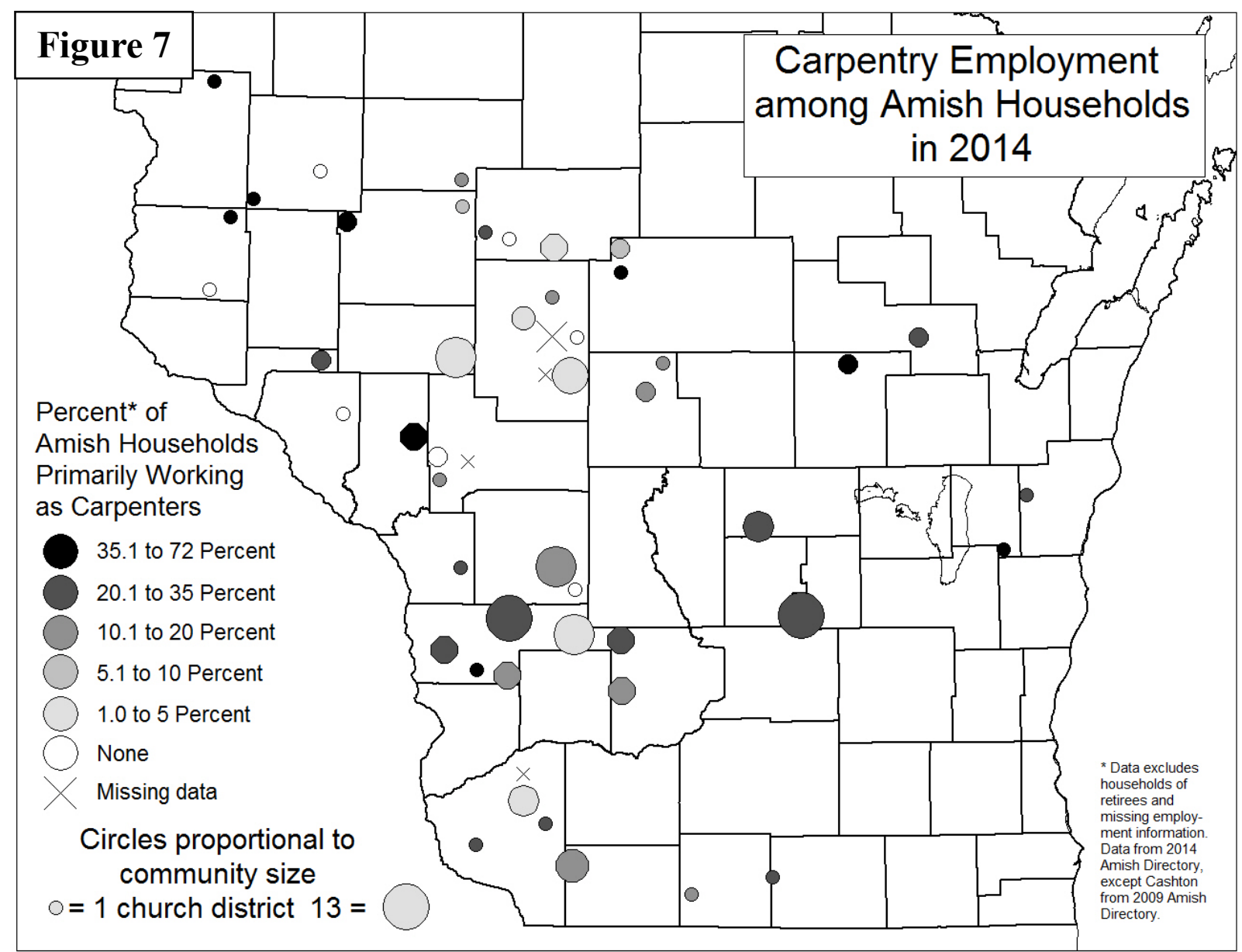

Percent of employed Amish households engaged in carpentry in 2014, by settlement. Primarily based upon occupation data in Amish directory (Miller 2014), supplemented by data in prior directory for several settlements (Miller 2009). Cartography by author.

\section{Woodworking}

Woodworking related employment-logging, sawmill work, furniture and cabinet making, and carpentry - is second only to farming as the principal occupation of household heads (Table 4). Woodworking engages 35 percent of the state's employed Amish households.

Those communities most reliant on woodworking are scattered across the state (Figure 6). Around 40 percent of all settlements have at least half of their households engaged in some aspect of woodworking. Wautoma, with four church districts, is the largest majoritywoodworking settlement. The highest proportion of employed household heads in woodworkers is in New Auburn (28 out of 31). The sheer quantity of woodworkers in the two largest Amish settlements, Kingston-Dalton and Cashton, is worth mentioning; even if not a majority, woodworkers outnumber farmers by only a slim margin.

Woodworking, itself, is a broad occupational category that hides some interesting trends. For example, Kingston (2014) and Cashton (2009) have around 25 percent of their household heads primarily in carpentry while Augusta (2014) has less than two percent (Figure 7). Yet, Augusta has nearly 20 percent of the state's Amish sawmill employment, whereas 


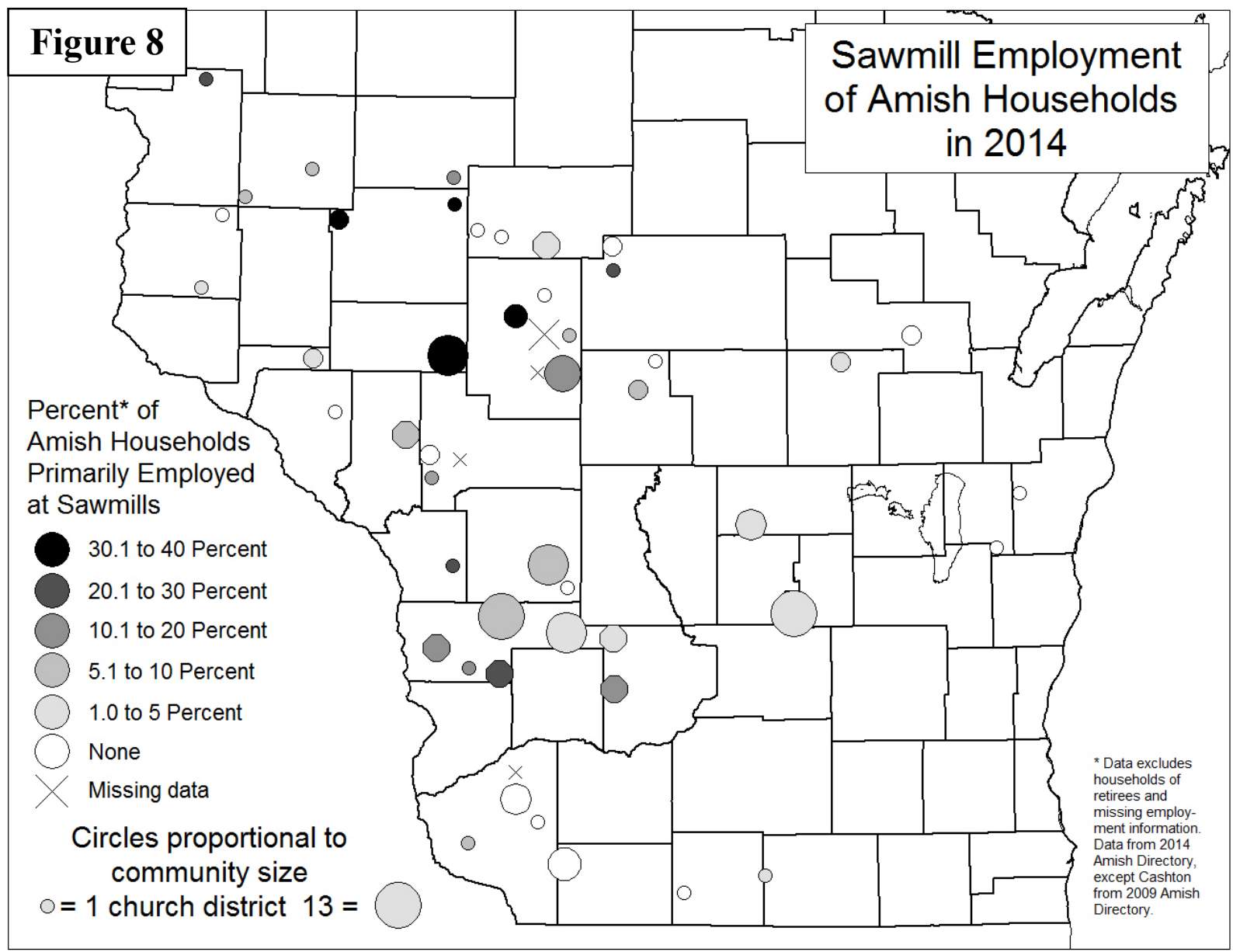

Percent of employed Amish households working at sawmills in 2014, by settlement. Primarily based upon occupation data in Amish directory (Miller 2014), supplemented by data in prior directory for several settlements (Miller 2009). Cartography by author.

hardly any Kingston families work at a sawmill (Figure 8). As for furniture making (Figure 9), the greatest involvement is in Loganville in Sauk County, which has three districts; there, 23 percent are employed in furniture manufacturing. Though much smaller, Loganville has about as many actual furniture makers as Kingston.

One in four ministers in the 2015 survey believed that woodworking employment would increase. Communities where over half of the respondents expected woodworking would increase include Cashton, Clear Lake, Loyal, Lublin, Milladore, Monroe, New Auburn, Readstown, St. Anna-Elkhart Lake, and Wautoma.

\section{Other Employment}

Although 92.6 percent of working households are primarily or secondarily employed in farming or woodworking, several other occupations are worthy of mention. Nine percent of Wisconsin's Amish households are primarily engaged in workshops, such as metal working. Around five percent—-particularly the households of younger adults—were "day labor" or "hired hand." A few were primarily engaged in retail stores or bakeries. One often sees candy and quilts for sale at Amish farmhouses, yet these activities are rarely listed as the household head's 


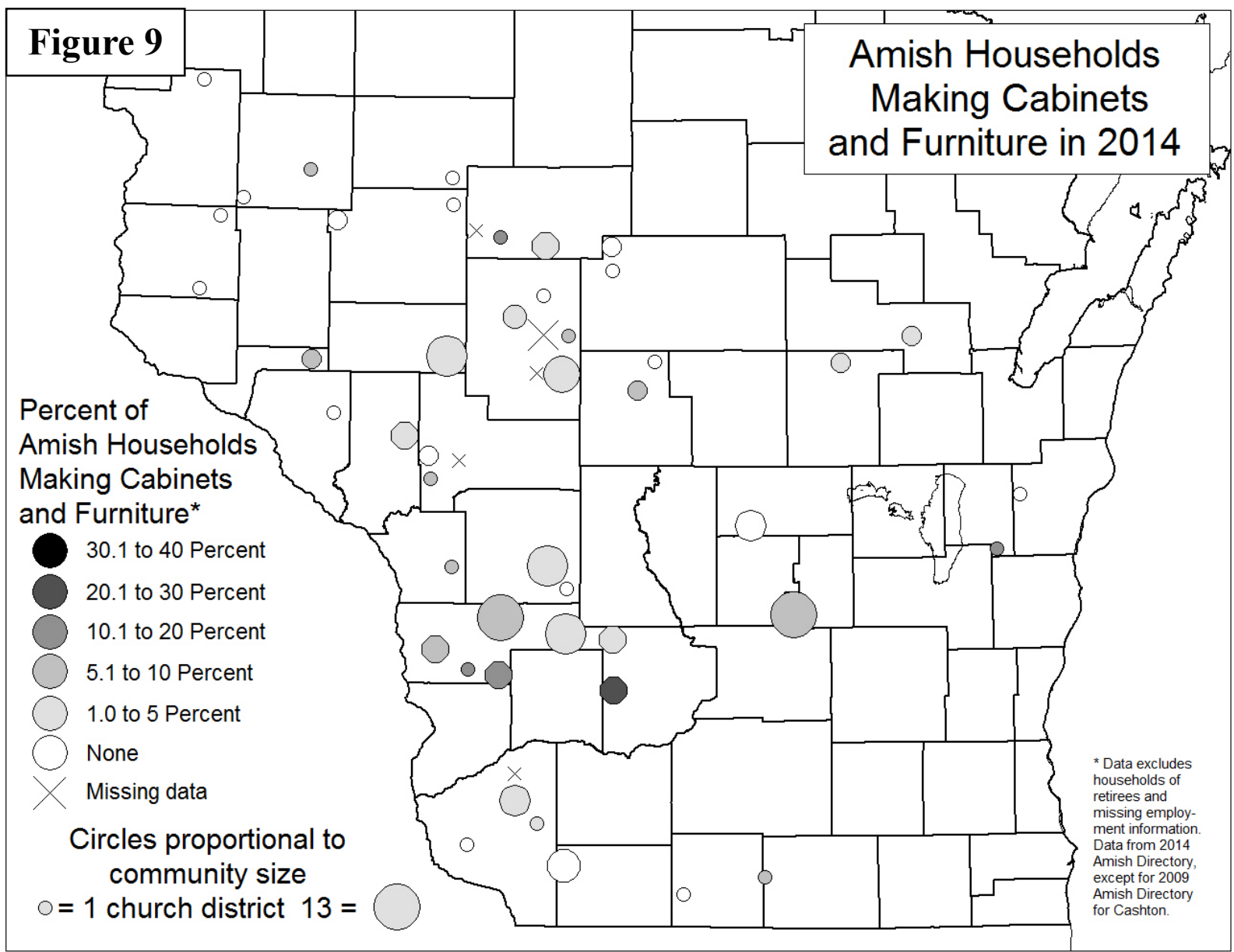

Percent of employed Amish households making cabinets and/or furniture in 2014, by settlement. Primarily based upon occupation data in Amish directory (Miller 2014), supplemented by data from prior directory for several settlements (Miller 2009). Cartography by author.

primary occupation. This is likely because they are economic activities of wives, whose occupations are not listed in directories. Likewise, many young females work in retail shops and bakeries, supplementing, but not providing, the primary income of their household.

\section{Primary Employment Pattern of Wisconsin Amish Settlements}

The primary employment category characterizing each Amish settlement varies (Figure 10). Those locales predominately engaged in farming far outnumber those primarily employed in woodworking. In one third of Wisconsin's Amish settlements, the difference between households employed in farming versus woodworking is greater than 40 percentage points (Table 5).

Farming-dominated settlements range from eight one-district settlements to the larger Hillsboro and Wilton settlements (eight districts as of 2014). In the two largest Amish settlementsCashton and Kingston-Dalton — farming employment slightly exceeded woodworking (Figure $10)$. 


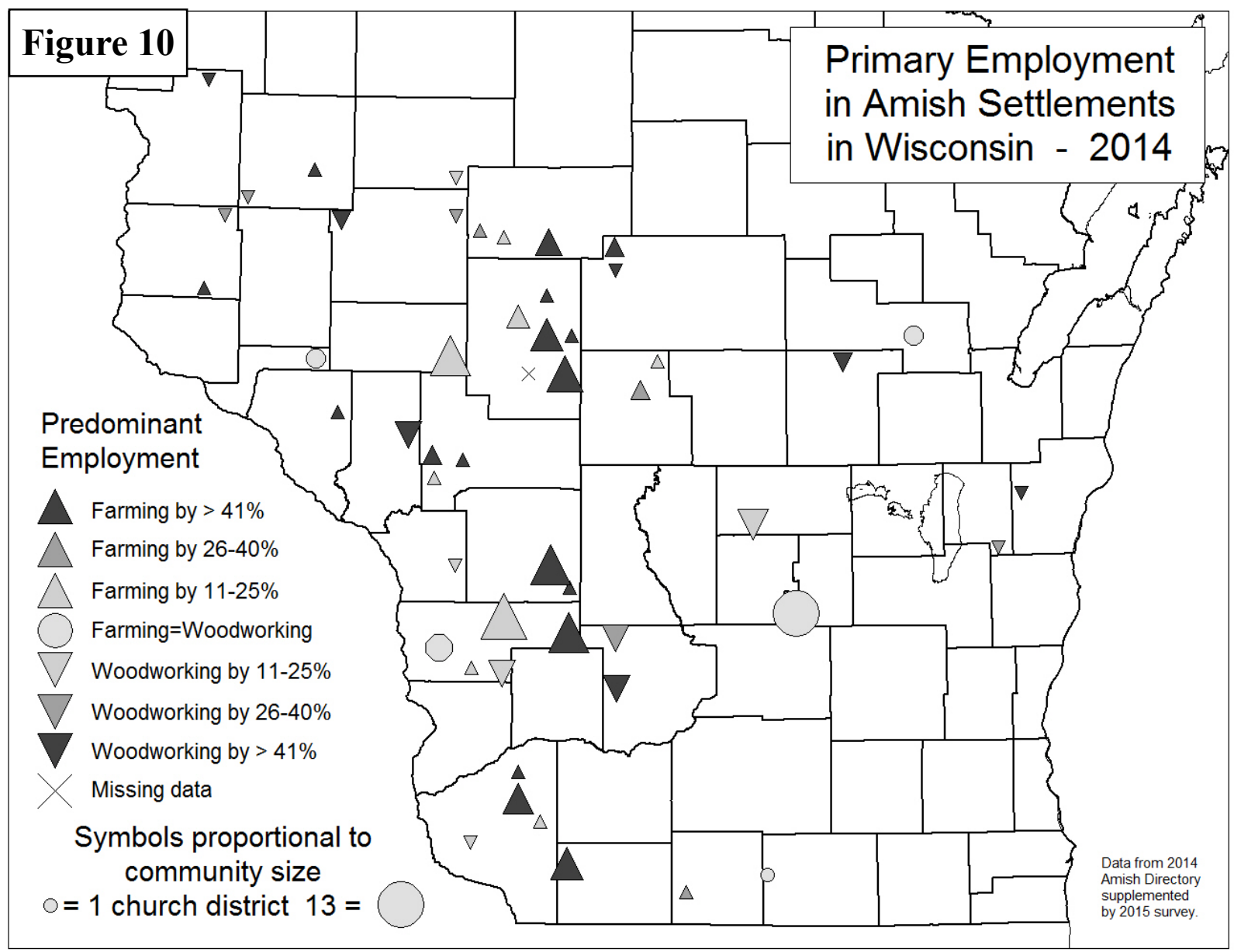

Primary type of occupation of Amish households in 2014, by settlement. Where employment in farming and woodworking are within ten percentage points of each other, it is mapped as being equal. Every place where employment in either farming or woodworking exceeds that in the other by 11 to 25 percentage points, it is mapped as "Farming by 11-25\%" or "Woodworking by 11-25\%." For example, in Augusta, 57 percent of the households are employed in farming while 43 percent are employed in woodworking; thus its primary employment is shown as "Farming by 11 to 25\%." Occupation data primarily from Amish directory (Miller 2014), supplemented by data in prior directory for several settlements (Miller 2009) and by mail survey conducted among Amish bishops and ministers in fall 2015. Cartography by author.

In her detailed analysis of the diversity of farming in the Cashton community a decade ago, Lynne Heasley $(2005,108)$ wrote, "Dairying and field crops were central, but also important were fruits, vegetables, maple syrup, and the occasional specialty plant." Yet she also notes the existence of 25 sawmills, which enabled the Amish to establish woodworking shops that provide "value added-income" (p. 118). Although 2014 occupation data were unavailable, it appears that both the Cashton and Kingston-Dalton settlements are moving towards parity in their leading occupations.

Geographic patterns of primary occupation engagement are discernable. In only one eastern Wisconsin Amish settlement does farming clearly outrank woodworking. In contrast, in a broad swath of settlements extending from southwestern Wisconsin (e.g. Platteville and Fennimore) to north-central Wisconsin (e.g. Medford) and including settlements such as Hillsboro, Wilton, Granton, and Loyal, the percent of households engaged in farming 
Table 5: Primary Employment in Wisconsin's Amish Settlements in 2014

\begin{tabular}{lcc}
$\begin{array}{l}\text { Employment: Farming vs. Woodworking, } \\
\text { Percentage Point Difference }\end{array}$ & $\begin{array}{c}\text { Number of } \\
\text { Settlements }\end{array}$ & $\begin{array}{c}\text { Percent of } \\
\text { Settlements }\end{array}$ \\
\hline Farming by $>41 \%$ & 17 & $34 \%$ \\
Farming by $26-40 \%$ & 3 & $6 \%$ \\
Farming by $11-25 \%$ & 8 & $16 \%$ \\
Farming $\approx$ Woodworking (within $10 \%)$ & 5 & $10 \%$ \\
Woodworking by $11-25 \%$ & 5 & $10 \%$ \\
Woodworking by $26-40 \%$ & 5 & $10 \%$ \\
Woodworking by $>41 \%$ & 6 & $12 \%$ \\
Missing data: No classification & 1 & $2 \%$ \\
\hline Total settlements in 2014 & 50 & $100 \%$
\end{tabular}

outnumbers the percent in woodworking by more than 25 percentage points. Just to the west, woodworking has greater prominence in the rougher topography of the Driftless Region. This region of southwestern and west central Wisconsin was not glaciated during the Pleistocene and is marked by steeply sloping valley sides and up to 500 feet of local relief. Cropland accounts for a smaller share of total farmland in these counties (NASS 2014) and the lands are more forested. Yet, in communities where woodworking is prominent, some households also have dairy herds; typically, between 20 and 40 percent of households are engaged in both activities.

\section{Occupations and the Influence of Amish Affiliations}

Petrovich (2017) has identified six Amish affiliations, five of which are in Wisconsin: Swartzentruber, Kenton, Andy Weaver, Old Order-mainstream, and New Order (Figure 11). What is the relationship between Amish affiliation and occupation?

Conservative Amish affiliations, namely Andy Weaver, Kenton, and Swartzentruber dominate most of the western half of the state. Of the four Swartzentruber Amish settlements with occupational data generated (Table 7), farming exceeded woodworking by over 10 percentage points and by 40 percentage points in two settlements. Greater diversity of household occupations exists among the Andy Weaver settlements. In six settlements, employment in farming exceeds woodworking by over 40 percentage points; the inverse holds in four settlements. Among the 18 Old Order-mainstream settlements, in seven communities, farming exceeds woodworking by 40 percentage points; in only one community is the inverse true. Wisconsin's two New Order settlements are both dominated by farming, with dairying employing over 55 percent of their households and farming overall exceeding woodworking by over 40 percentage points. 


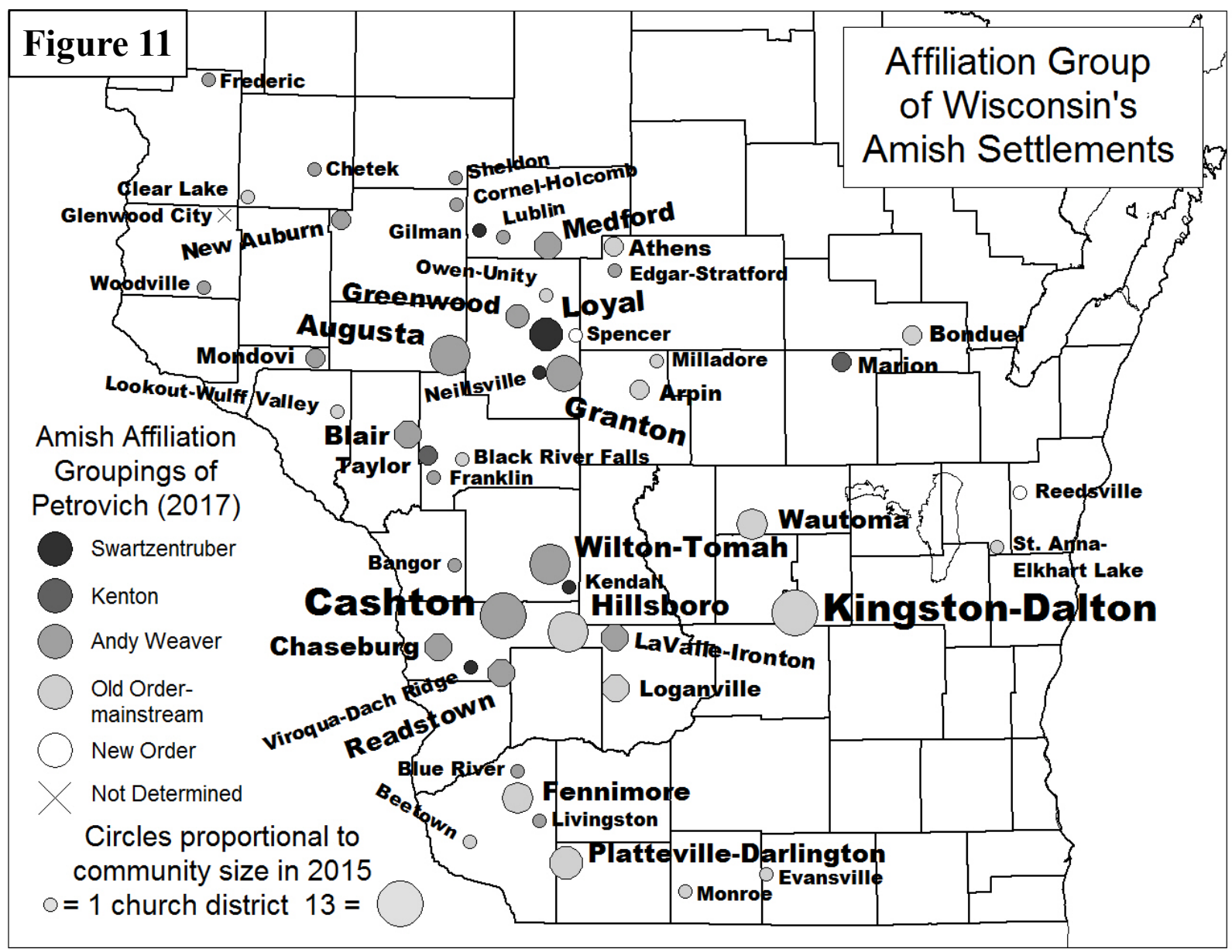

Affiliation grouping of Wisconsin's Amish settlements by classification scheme proposed by Petrovich (2017), using data provided by Burdge (2016). Twenty-three settlements have the ultraconservative Andy Weaver affiliation, two the even more conservative Kenton group, and five are the most conservative Swartzentruber Amish. Eighteen settlements are within the mainstream Old Order Amish, while two are classified as more progressive New Order Amish. The classification of one settlement is unknown. While the Hillsboro settlement is classified as having an Old Order mainstream affiliation, it displays some Reformist characteristics. Cartography by author.

An affiliation's Ordnung addresses the technologies utilized in dairying, including whether milk is stored and shipped in ten-gallon cans or bulk tanks and how crops are harvested and handled at the barn (Cross 2004; 2014). In six of the 22 Andy Weaver settlements and two of the 16 Old Order-mainstream settlements for which statistics are available, fewer than 20 percent of households have a dairy herd. Yet, among Wisconsin's larger Amish settlements with at least forty percent of households with a dairy herd, all are Andy Weaver (Cashton, Granton, and Wilton). Thus, Wisconsin's Andy Weavers have not as conspicuously "moved away from farming” as Holmes County’s Andy Weavers (Hurst and McConnell 2010, 191).

Furthermore, all of these larger Wisconsin communities and most of the smaller Andy Weaver settlements are reliant upon milk cans for transporting their milk, although storing milk in cans is not an option for Amish dairy farmers in several small Andy Weaver settlements. 


\section{Table 7: Total Wisconsin Amish Settlements by Affiliation and Occupation}

\begin{tabular}{|c|c|c|c|}
\hline \multirow[b]{2}{*}{ Affiliation } & \multicolumn{3}{|c|}{ Primary Occupation in Settlement } \\
\hline & Farming $>25 \%$ & Farming $\approx$ Woodworking ${ }^{1}$ & Woodworking $>25 \%$ \\
\hline Swartzentruber $^{2}$ & 3 & 1 & 0 \\
\hline Andy Weaver & 6 & 11 & 6 \\
\hline Old Order-mainstream & 9 & 6 & 3 \\
\hline New Order & 2 & 0 & 0 \\
\hline Kenton & 1 & 0 & 1 \\
\hline
\end{tabular}

${ }^{1}$ Employment in all varieties of farming and all varieties of woodworking are relatively equal, with the percentage point of the households in the settlement having farming occupations and the percentage point having woodworking occupations within 25 percent of each other.

${ }^{2}$ Insufficient information regarding one Swartzentruber settlement to classify the primary occupation of its households.

Among Wisconsin's Old Orders, can milk is the norm within its largest settlement, Kingston, where 25 percent of the households have a dairy herd. Conversely, bulk tanks are used in the Arpin, Athens, Fennimore, and Platteville settlements, which all have over 40 percent of their households engaged in dairying. We can speculate that differences in engagement with dairying and utilization of bulk tanks may be linked to the origins of these Old Order mainstream settlements. Kingston is linked with the Elkhart-LaGrange, IN, settlement, while Athens, Fennimore, and Platteville share a Lancaster County, PA, connection. Dairy herds and income are considerably larger within settlements that utilize bulk tanks.

Ordnung may also influence the character of woodworking, such as whether power tools are used or what mechanism powers woodworking equipment and sawmills. Likewise, some settlements welcome customers into their woodworking shops and stores while others market their products through middlemen. However, religious affiliation cannot be easily linked to a settlement focus on woodworking.

\section{Amish Occupations: Change in the Future?}

Only a gradual shift in occupations is anticipated by Amish religious leaders. This is true both when broadly considering farming versus woodworking occupations and when focusing specifically on engagement in dairying and produce farming. In a quarter of Wisconsin Amish settlements, employment in some aspect of woodworking — ranging from logging and sawmill jobs to generic woodworking, cabinet and furniture making, and carpentry-now supplants farming as the primary occupation. Nevertheless, statewide, more Amish households still remain engaged in farming. Yet, households with a dairy herd only slightly outnumber those employed in woodworking. Such findings beg for additional research, inquiries that need to go beyond simple occupation surveys and reliance upon employment data from directories.

Foremost, research documenting gross sales and net farm income coming from produce farming might better illustrate the linkage between the expansion of auction houses and produce farming. This may explain why the proportion of Amish farmers who have dairy herds is declining. Because many households are engaged in several activities - even if only one type of employment is listed in the directory - more research is needed to explore the roles of cottage 
industries and sales of miscellaneous farm products and handicrafts in contributing to household income, as Foster (1984) suggested several decades ago. This includes research on women's economic contributions, beyond those associated with traditional household duties as wife.

Likewise, a better appreciation of the role of unspecified off-farm employment - such as day labor - in both supporting the primary farming and woodworking occupations, as well as contributing to household income should be fruitful. The seasonal character of day labor, both in totality of employment and shifts from agriculture to forest related activities or from outdoor work to workshops, should be better documented.

Finally, as Amish settlements grow in size, with many types of employment available beyond farming and woodworking, do we find that the density of the Amish population or its rate of population growth is related to employment opportunities?

\section{References}

Anderson, Cory and Loren Kenda. 2015. "What Kinds of Places Attract and Sustain Amish Populations?" Rural Sociology 80(4):483-511. https://doi.org/10.1111/ruso.12083

Burdge, Edsel, Jr. 2016. "WI Amish Settlements with Affiliations.” Unpublished tabulation dated February 2, 2016, from Young Center for Anabaptist and Pietist Studies, Elizabethtown College, Pennsylvania. Based on data originally compiled by Stephen Scott.

Cross, John. 2003. “Amish Surnames, Settlement Patterns, and Migration.” Names 51(3-4):193-214. https://doi.org/10.1179/nam.2003.51.3-4.193

—. 2004. "Expansion of Amish Dairy Farming in Wisconsin." Journal of Cultural Geography 21(2):77101. https://doi.org/10.1080/08873639009478260

—. 2007. "The Expanding Role of the Amish in America's Dairy Industry." Focus on Geography 50(3):7-16. https://doi.org/10.1111/j.1949-8535.2007.tb00199.x

-. 2014. "Continuity and Change: Amish Dairy Farming in Wisconsin Over the Past Decade." The Geographical Review 104(1):52-70. https://doi.org/10.1111/j.1931-0846.2014.12004.x

—. 2015. "Change and Sustainability Issues in America's Dairyland." Focus on Geography 58(4):173-83. https://doi.org/10.1111/foge.12060

—. 2016. "Dairying Landscapes of the Amish in Wisconsin." Material Culture 48(2):16-31.

Day-Farnsworth, Lindsey, Brent McCown, Michelle Miller, and Anne Pfeiffer. 2009. Scaling Up: Meeting the Demand for Local Food. Madison, WI: University of Wisconsin Extension and Center for Integrated Agricultural Systems. (CIAS002) I-12-09. Last Accessed 19 January 2017 (http://www.cias.wisc.edu/wp-content/uploads/2010/01/baldwin_web_final.pdf).

Dillman, Don. 1978. Mail and Telephone Surveys: The Total Design Method. New York, NY: John Wiley and Sons.

Donnermeyer, Joseph. 2015. "Doubling Time and Population Increase of the Amish." Journal of Amish and Plain Anabaptist Studies 3(1):94-109. https://doi.org/10.18061/1811/69364

Donnermeyer, Joseph, and Cory Anderson. 2015. "A Mid-Decade Update on Amish Settlement Growth." Journal of Amish and Plain Anabaptist Studies 3(2):222-35. https://doi.org/10.18061/1811/75348

Donnermeyer, Joseph, and David Luthy. 2013. “Amish Settlements across America: 2013." Journal of Amish and Plain Anabaptist Studies 1(2):107-29. https://doi.org/10.18061/1811/57700

Ericksen, Eugene, Julia Ericksen, and John Hostetler. 1980. "The Cultivation of the Soil as a Moral Directive: Population Growth, Family Ties, and the Maintenance of Community among the Old Order Amish.” Rural Sociology 45(1):49-68. 
Foster, Thomas. 1984. "Occupational Differentiation and Change in an Ohio Amish Settlement." Ohio Journal of Science 84(3):74-81.

Heasley, Lynne. 2005. A Thousand Pieces of Paradise: Landscape and Property in the Kickapoo Valley. Madison, WI: University of Wisconsin Press.

Hurst, Charles, and David McConnell. 2010. An Amish Paradox: Diversity and Change in the World's Largest Amish Community. Baltimore, MD: Johns Hopkins University Press.

Johnson-Weiner, Karen. 2014. "Technological Diversity and Cultural Change among Contemporary Amish Groups." Mennonite Quarterly Review 88(1):5-22.

Kraybill, Donald, Karen Johnson-Weiner, and Steven Nolt. 2013. The Amish. Baltimore, MD: Johns Hopkins University Press.

Kreps, George, Joseph Donnermeyer, and Marty Kreps. 1994. "The Changing Occupational Structure of Amish Males.” Rural Sociology 59(4):708-19. https://doi.org/10.1111/j.1549-0831.1994.tb00556.x

Lowery, Sean, and Allen Noble. 2000. "The Changing Occupational Structure of the Amish of the Holmes County, Ohio, Settlement." The Great Lakes Geographer 7(1):26-37.

Meyers, Thomas. 1994. "Lunch Pails and Factories." Pp. 165-81 in The Amish Struggle with Modernity, edited by Donald Kraybill and Marc Olshan. Hanover, NH: University Press of New England.

Miller, Devon (ed.). 2002. Wisconsin, Minnesota and Minnesota Amish Directory 2002. Millersburg, OH: Abana Books.

Miller, Edward E. (ed.). 2014. Wisconsin Amish Directory 2014. Self-published.

Miller, Perry (ed.). 2009. Wisconsin Amish Directory 2009. Self-published.

National Agricultural Statistics Service (NASS). 2014. "Acres of Total Cropland as Percent of Land in Farms Acreage: 2012.” 2012 Agricultural Atlas of the United States. Last accessed 13 January 2017. (https://www.agcensus.usda.gov/Publications/2012/Online_Resources/Ag_Atlas_Maps/Farms/Land_i n_Farms_and_Land_Use/12-M086-RGBChor-largetext.pdf).

Nethers, John. 1983. "Occupational Changes among the Old Order Amish in the Holmes County Vicinity of Ohio." Communal Societies Quarterly (Fall):122-39.

Nolt, Steven, and Thomas Meyers. 2007. Plain Diversity: Amish Cultures and Identities. Baltimore, MD: Johns Hopkins University Press.

Petrovich, Christopher. 2017. "More Than Forty Amish Affiliations? Charting the Fault Lines." Journal of Amish and Plain Anabaptist Studies 5(1):120-42. https://doi.org/10.18061/1811/81072

Raber, Aden. 2016. The New American Almanac, 47 $7^{\text {th }}$ Edition. Baltic, OH: Aden B. Raber.

Scott, Stephen. 2009. “Amish Group Descriptions.” Unpublished document dated June 10, 2009.

Smith, Stephen, Jill Findeis, Donald Kraybill, and Steven Nolt. 1997. "Nonagricultural Micro-enterprise Development among the Pennsylvania Amish: A New Phenomenon." Journal of Rural Studies 13(3):237-51. https://doi.org/10.1016/S0743-0167(97)00018-1

Troyer, Henry, and Lee Willoughby. 1984. "Changing Occupational Patterns in the Holmes County, Ohio Amish Community." Pp. 52-80 in Internal and External Perspectives on Amish and Mennonite Life 1, edited by Werner Enninger. Essen, Germany: Unipress.

Wasao, Samson, and Joseph Donnermeyer. 1996. "An Analysis of Factors Related to Parity among the Amish in Northeast Ohio." Population Studies 50(2):235-46. https://doi.org/10.1080/0032472031000149326

Young Center for Anabaptist and Pietist Studies. 2016. "Amish Population by State/Province, 2016." Young Center for Anabaptist and Pietist Studies, Elizabethtown College. Last accessed 5 January 2017 (http://groups.etown.edu/amishstudies/statistics/population-by-state/). 